\title{
The Civitavecchia Coastal Environment Monitoring System (C-CEMS): a new tool to analyze the conflicts between coastal pressures and sensitivity areas
}

\author{
S. Bonamano ${ }^{1}$, V. Piermattei ${ }^{1}$, A. Madonia ${ }^{1}$, F. Paladini de Mendoza ${ }^{1}$, A. Pierattini ${ }^{1}$, R. Martellucci ${ }^{1}$, C. Stefanì ${ }^{1}$, \\ G. Zappalà ${ }^{2}$, G. Caruso ${ }^{2}$, and M. Marcelli ${ }^{1}$ \\ ${ }^{1}$ Laboratory of Experimental Oceanology and Marine Ecology (LOSEM), DEB - \\ University of Tuscia, Molo Vespucci, Port of Civitavecchia, Civitavecchia 00053, Rome, Italy \\ ${ }^{2} \mathrm{CNR}$ - Istituto per l'Ambiente Marino Costiero, Messina, Italy
}

Correspondence to: S. Bonamano (simo_bonamano@unitus.it)

Received: 29 June 2015 - Published in Ocean Sci. Discuss.: 28 July 2015

Revised: 17 December 2015 - Accepted: 21 December 2015 - Published: 15 January 2016

\begin{abstract}
The understanding of the coastal environment is fundamental for efficiently and effectively facing the pollution phenomena as expected by the Marine Strategy Framework Directive, and for limiting the conflicts between anthropic activities and sensitivity areas, as stated by Maritime Spatial Planning Directive. To address this, the Laboratory of Experimental Oceanology and Marine Ecology developed a multi-platform observing network that has been in operation since 2005 in the coastal marine area of Civitavecchia (Latium, Italy) where multiple uses and high ecological values closely coexist. The Civitavecchia Coastal Environment Monitoring System (C-CEMS), implemented in the current configuration, includes various components allowing one to analyze the coastal conflicts by an ecosystem-based approach. The long-term observations acquired by the fixed stations are integrated with in situ data collected for the analysis of the physical, chemical and biological parameters of the water column, sea bottom and pollution sources detected along the coast. The in situ data, integrated with satellite observations (e.g., temperature, chlorophyll $a$ and TSM), are used to feed and validate the numerical models, which allow the analysis and forecasting of the dynamics of pollutant dispersion under different conditions. To test the potential capabilities of C-CEMS, two case studies are reported here: (1) the analysis of fecal bacteria dispersion for bathing water quality assessment, and (2) the evaluation of the effects of the dredged activities on Posidonia meadows, which make up most of the two sites of community importance located
\end{abstract}

along the Civitavecchia coastal zone. The simulation outputs are overlapped by the thematic maps showing bathing areas and Posidonia oceanica distribution, thus giving a first practical tool that could improve the resolution of the conflicts between coastal uses (in terms of stress produced by anthropic activities) and sensitivity areas.

\section{Introduction}

Coastal ecosystems are characterized by multiple human activities such as aquaculture, energy production, maritime transport, tourism, and fishery that coexist both spatially and temporally in these areas. The overlap of such activities and their objectives leads to the generation of user-user and userenvironment conflicts (Douvere, 2008) that result in increasingly undesirable effects such as loss and destruction of habitat, pollution, climate change, over-fishing, and cumulative threats to the oceans and human health as a whole.

The Integrated Marine Policy (IMP) has faced this issue by the adoption of the Maritime Spatial Planning Directive (MSP, 2014/89/EU), whose main purpose is to promote the sustainable management of uses and conflicts in coastal areas through an ecosystem-based approach. The MSP strategy allows one to minimize the impacts on sensitivity areas, also enabling the achievement of the Good Environmental Status (GES) by 2020, requested by the Marine Strategy Framework Directive (MSFD 2008/56/EC). In the last few years, a con- 
certed" effort has been made by the scientific community to provide new approaches for the analysis of GES descriptors, like the study of eutrophication (Descriptor 5) through satellite ocean color data (Cristina et al., 2015) and the assessment of sea-floor integrity (Descriptor 6) by SAR imagery (Pieralice et al., 2014). Important results have also been obtained by the analysis of both commercial fishes and food web (descriptors 3 and 4), to assess the environmental status of European seas (Jayasinghe et al., 2015) and the levels of major contaminants (descriptors 8 and 9) and their pollution effects on aquatic biota (Tornero and Ribera d'Alcalà, 2014).

In line with the holistic approach pursued by the MSFD, the achievement and the maintenance of marine ecological standards need the support of monitoring networks that use L-TER (long-term ecological research) observations and integrate multi-disciplinary data sets, fundamental to forecasting specific events (Schofield et al., 2002). So, it is necessary to develop observational monitoring systems in the southern European coastal areas capable of collecting both highresolution and long-term data and building multi-disciplinary data sets.

Recent advances in communication and sensor technology have led to the development of worldwide multi-platform networks that provide a significant amount of data on different spatial and temporal scales for the study of oceanographic processes and marine ecosystem monitoring (Glasgow et al., 2004; Hart and Martinez, 2006; Kröger et al., 2009). These observational systems are especially suited for the monitoring of coastal areas (i.e., the Chesapeake Bay Observing System, CBOS; Li et al., 2005; the Long-term Ecosystem Observatory, LEO-15; Schofield et al., 2002) where many of the processes related to natural or anthropic events (pollution spilling, water discharges, river plume, etc.) are often episodic and occasional; consequently, they are scarcely identifiable using traditional methods (Schofield et al., 2002). Only an integrated and multi-platform approach, which combines data and forecast models, allows the characterization of the different events and conflicts in coastal waters (Smith et al., 1987; Glenn et al., 2000; Haidvogel et al., 2000). Improved modeling and real-time sensing capabilities in terms of accuracy and spatial and temporal resolution are required, also in order to respond to both science and societal needs (Tintoré et al., 2013). In particular, linking observations and models has been recognized as a critical step to achieving effective integrated ecosystem assessment (Malone et al., 2014). The mathematical models play a fundamental role in the global and regional ocean forecasting systems since they assimilate the observational data in order to produce reanalysis and forecast products of the most relevant ocean and physical variables (Tonani et al., 2015). Most of the regional operational systems in the Mediterranean Sea are included in the Mediterranean Forecasting System (MFS), such as the Adriatic Forecasting System (Oddo et al., 2005), the Sicily Channel Regional Model (Olita et al., 2012), the Tyrrhenian Sea Forecasting (Vetrano et al., 2010), the Aegean-Levantine
Forecast System (Korres and Lascaratos, 2003) or the Western Mediterranean Operational Forecasting System (Juza et al., 2015). Most of the MSF products are disseminated by the MyOcean project (http://marine.copernicus.eu) that, together with satellite and in situ observations, developed the preoperational European Copernicus marine service. However, several simulations in the Mediterranean Sea are based on basin-scale features and metrics (Tonani et al., 2008; Oddo et al., 2009; Vidal-Vijande et al., 2011), partially because of the lack of data at sub-basin scale. A recent study by Crise et al. (2015) revealed gaps of data in the Mediterranean region (southern European seas), highlighting the scarcity, dispersion and heterogeneity of coastal water data sets. Conversely, the advancement from global- to regional- and localscale modeling, which is necessary to analyze and forecast the pollution phenomena in coastal areas, is applicable only in the region where a large amount of observation data exist.

As a first step in this direction, the Laboratory of Experimental Oceanology and Marine Ecology developed a multi-platform observing network that has been operating since 2005 in the coastal marine area of Civitavecchia (Italy, Tyrrhenian Sea, western Mediterranean Sea), critically affected by the presence of many conflicts.

This paper presents the Civitavecchia Coastal Environment Monitoring System (C-CEMS) as a tool to support the management of conflicts between anthropic uses and sensitivity areas. It focuses on (1) the functioning of C-CEMS and its components (Sect. 3), (2) its capabilities in estimating the dispersion of fecal bacteria for bathing water quality assessment and of dredged fine sediments to evaluate the effects on Posidonia oceanica meadows present in the sites of community importance (SCI; Sect. 4), and (3) the resulting analysis of "urban discharge - bathing area" and "dredging - SCI" conflicts (Sect. 5).

\section{Study area}

The study area is located along the northeastern Tyrrhenian coast (western Mediterranean Sea; Fig. 1a). The circulation of the Tyrrhenian basin is affected by mesoscale and seasonal variability (Hopkins, 1988; Pinardi and Navarra, 1993; Vetrano et al., 2010). The presence of a cyclonic gyre with a very pronounced barotropic component suggests that the wind plays a major role as a forcing agent (Pierini and Simioli, 1998). Like most of the Italian coast, the northeastern Tyrrhenian one counts many tourist and industrial areas primarily used for maritime transport and energy production, involving an intense exploitation of marine resources. Nevertheless, it houses several biodiversity hotspots and marine protected areas for the conservation of priority habitats and species.

In particular, this study is focused on the coastal zone between Marina di Tarquinia and Macchia Tonda in the northern Latium region of Italy (Fig. 1b) including Civitavecchia, 


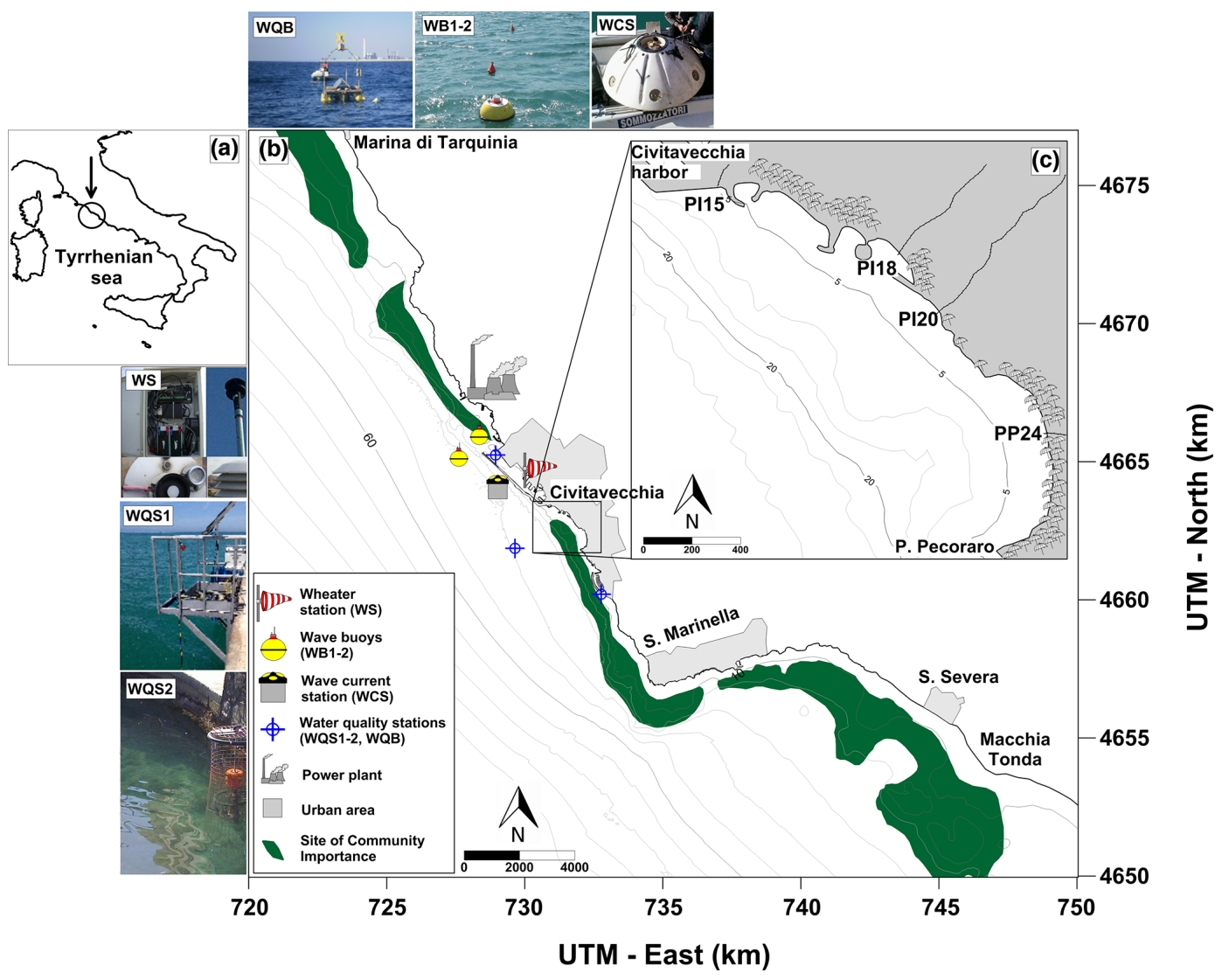

Figure 1. Location of the study area along the northeastern Tyrrhenian coast of Italy (western Mediterranean Sea, a). Zoom-in on the area of C-CEMS application: the location of coastal uses, SCIs, and measurement stations indicated (b) and the Civitavecchia bathing areas with discharge points and bather density indicated (one umbrella corresponds to five bathers, $\mathbf{c}$ ). The fixed station pictures are reported in the top-left corner of the figure. The coordinate system is expressed in UTM 32 (WGS84).

where all the above-mentioned uses could produce potential conflicts. The Civitavecchia harbor is one of the largest in Europe in terms of cruise and ferry traffic; it represents a fundamental point of commercial exchange in Europe. Thanks to the new Port Regulating Plan, the port of Civitavecchia has increased its commercial traffic and cruise passenger flow. The Interministerial Committee for Economic Planning (CIPE) approved the final project for the "strengthening of Civitavecchia harbor hub - first parcel functional interventions: Cristoforo Colombo embankment extension, ferries and services docks realization" (Decision 140/2007, 2008). All of these operations involve the handling of significant quantities of sediments; the impacts of dredging on the adjacent natural ecosystems can be varied and difficult to predict (Windom, 1976; Cheung and Wong, 1993; Lohrer and Wetz, 2003; Zimmerman et al., 2003; Nayar et al., 2007). Many studies have recently focused on the importance of management of dredged sediments in harbor areas (Cappucci et al., 2011; Cutroneo et al., 2014; Bigongiari et al., 2015). In conflict with the port activities, the study area hosts four SCIs. They are characterized by the presence of habitats (Posidonia oceanica meadows and reefs of rocky substrates and bio- genic concretions) and species (Pinna nobilis and Corallium rubrum) enclosed in attachments 1 and 2 of European Union (EU) directive 92/43/EEC.

Moreover, the promotion of underwater natural beauty, touristic exploitation connected to the increased cruise traffic and the realization of new bathing facilities has led to a drastic increase in the population density in Civitavecchia during the summer. Many services are now available for recreation thanks to the several beach licenses granted for food, bathing, mooring of private vessels, and sport activities. An updated list of the Latium Regional Office contains 72 beach licences released in 2014 to the municipal districts of Santa Marinella and Civitavecchia. However, this urban development was not associated with an improvement in the wastewater treatment plant, which often caused the discharge of untreated water into the bathing areas. Along the coast, between Civitavecchia harbor and the Punta del Pecoraro bathing areas, four discharge points have been identified as shown in Fig. 1c, in conflict with the recreational use of the coastal zone. These discharge points present high concentrations of pathogenic bacteria deriving from fecal contamination episodes. 


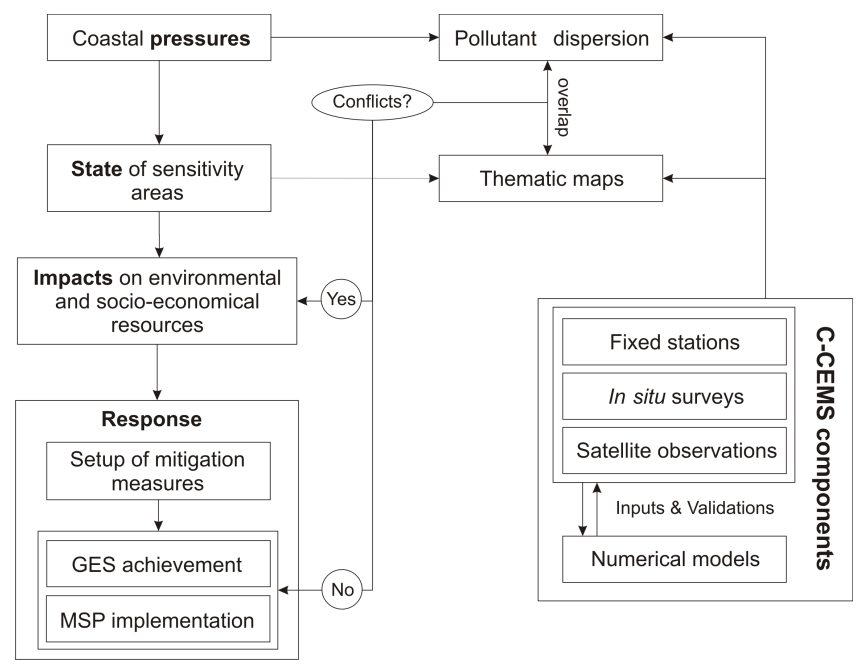

Figure 2. The role of C-CEMS in the analysis of the conflicts between coastal pressures, in terms of pollutant dispersion, and sensitivity areas, represented by thematic maps. This observing system includes different components such as fixed stations, in situ surveys, satellite observations and numerical models. The components interact between them to transfer data (by input I and validation V) from the in situ and satellite observations to numerical models in order to reach enough temporal and spatial resolution to analyze the pollutant dispersion in coastal waters. Only if conflicts between anthropic activity and sensitivity areas occur are the potential impacts on environment and socio-economical resources analyzed (Impacts) and suitable mitigation measures applied (Response) in order to achieve Good Environmental Status (GES) and implement Marine Spatial Planning Directive (MSPD).

\section{Components of the C-CEMS}

C-CEMS is a multi-platform observing system implemented in 2005 to face the coastal conflicts by an ecosystem-based approach. According to the Copernicus program, C-CEMS provides a monitoring service for the marine environment through multi-source data including in situ and remote sensing observations. In addition, C-CEMS integrates this information within mathematical models that allow one to simulate specific events and forecast potential impacts with a high spatial and temporal resolution, necessary for analyzing the conflicts in coastal areas (Bonamano et al., 2015b).

The workflow reported in Fig. 2 shows the interaction between the C-CEMS components and its functioning within the Driver-Pressure-State-Impact-Response (DPSIR) scheme. C-CEMS allows one to assess the coastal pressures (Pressure) through the analysis of the dispersion of pollutants connected to the anthropic activities of the Civitavecchia area. It also enables one to obtain thematic maps giving information about the sensitivity areas (State) represented mainly by marine protected areas and zones designated for recreational uses (bathing, diving, watersports, fishing, etc.). The overlap between them makes a fundamental contribution to GES achievement and MSP implementation, also playing a crucial role in the detection of the ongoing conflicts. If a conflict occurs, C-CEMS helps in the analysis of its potential impacts (Impact) on environment and socio-economical resources, supporting the choice of the best mitigation practices to be applied (Response).

The workflow also indicates all of the components of the C-CEMS that are described in detail in the following paragraphs.

Fixed stations. Time series data collection is fundamental to improving the ability to control and forecast spatial and temporal variations in a marine environment. Fixed stations were installed along the Civitavecchia coast to acquire physical, chemical, and biological data, as shown in Fig. 1. In particular, a weather station (WS) acquires every $10 \mathrm{~min}$ wind speed, wind direction, air temperature, air pressure, humidity and solar radiation. The wind speed and direction represent the main forcing of the hydrodynamic model, while the solar radiation data are used as input in the water quality model. Two buoys (WB1 offshore, WB2 nearshore) measure every $30 \mathrm{~min}$ wave statistical parameters (significant height, peak period, and mean direction). The wave model is fed with WB1 data and then validated with the wave height data collected by WB2. An acoustic Doppler profiler, ADP (WCS), deployed on a Barnacle seafloor platform, acquires both current (with an acquisition rate of $20 \mathrm{~min}$ ) and wave height and direction (at intervals of $3 \mathrm{~h}$ ). The current velocity components are employed for the validation of the hydrodynamic model. Three water quality fixed stations, one buoy (Water Quality Buoy, WQB) outside the Civitavecchia harbor, and two coastal stations (WQS1 and WQS2) make it possible to acquire every $20 \mathrm{~min}$ sub-superficial sea temperature, conductivity (salinity, density), $\mathrm{pH}$, dissolved oxygen, fluorescence of chlorophyll $a$, and turbidity. In order to validate the satellite ocean color data, chlorophyll $a(\mathrm{Chl} a)$ and total suspended matter (TSM) data acquired by WQB were calibrated with the concentrations obtained by the water sample analyses. The physical and biological parameters of the WQS1 and WQS2, as well as those acquired by satellite observations, are used as initial conditions of the water quality model.

WQB and WQS data are processed following the SeaDataNet parameter quality control procedures: daily validated data sets are produced in order to monitor in near real time the water quality; Edios xml files are provided for monthly time series and stored following ISO 19139 and ISO 19115 formats provided for metadata.

In situ surveys. A spatial extension of the observatory system is provided by in situ collected data. The sampling strategy was conceived within the scope and context of the project objectives in order to select the most appropriate and efficient sampling approach. The field surveys typically include periodic and ad hoc activities. The first concern the measurement of the physical, chemical and biological variables of the water column using multiparametric probes and seawater samples. Data acquired during periodic surveys are used 
to validate and integrate the satellite observations in order to give the spatial distributions of the seawater parameters as the initial conditions of the water quality model. The ad hoc samplings are carried out in order to define the nature and composition of the sea bottom and to analyze the indicators of pollution near the human activity outputs. These data feed the water quality model for the estimate of the bottom shear stress, as well as the dispersion and/or the decay of pollutants in the nearshore coastal waters.

Satellite observations. Remote sensing data are essential to provide synoptic and extensive maps of biological and physical properties of the oceans (Schofield et al., 2002). Recently, Earth observation (EO) data have also been used to investigate the dynamic processes at high spatial resolution along the Italian coasts (Filipponi et al., 2015; Manzo et al., 2015). A few studies, among them Cristina et al. (2015), demonstrated the usefulness of remote sensing for supporting the MSFD, using MEdium Resolution Imaging Spectrometer (MERIS) sensor products. Similarly, we exploited both ocean color from the Moderate Resolution Imaging Spectroradiometer (MODIS) sensor and thermal infrared color from the Advanced Very High Resolution Radiometer (AVHRR) to obtain daily Chl $a$, TSM and sea surface temperature (SST) data. Such sensor data were chosen for their availability both in the region of interest and in the period of C-CEMS data acquisition.

To estimate Chl $a$ concentration, the MedOC3 bio-optical algorithm was applied (Qin et al., 2007; Santoleri et al., 2008), while TSM was estimated from the 645 normalized water-leaving radiance $(645 \mathrm{nLw})$ by applying the MUMM NIR atmospheric correction (Ruddick et al., 2006; Ondrusek et al., 2012).

Chl $a$ and TSM data collected by WQB and periodic in situ surveys were used to validate the algorithms used for remote sensing data. A work is in progress to implement a local algorithm specifically developed in the area of interest (CASE II waters) in order to reach a better quantification of Chl $a$ and TSM concentrations along the study area (Cui et al., 2014). In accordance with the Copernicus vision, the future development of this module considers integrating EO data coming from the Optical High-Resolution Sentinel sensors (Drusch et al., 2012), in order to increase the spatial resolution for a more accurate analysis of coastal dynamic processes.

Numerical models. Mathematical models play a key role in the C-CEMS, enabling one to analyze coastal processes at high spatial and temporal resolution. In this context, the entire data sets collected by fixed stations, satellite observations, and in situ samplings were employed as input conditions and as a validation of the numerical simulations. The mathematical models used in C-CEMS included the DELFT3D package, specifically DELFT3D-FLOW (Lesser et al., 2004), to calculate marine current velocity, SWAN (Booij et al., 1999) to simulate the wave propagation toward the coast, and DELFT3D-WAQ (Van Gils et al., 1993; Los et al., 2004) to reproduce the dispersion of conservative and non-conservative substances. The governing equations of these models are described in detail in Lesser et al. (2004) and Bonamano et al. (2015a).

The DELFT3D-FLOW model domain is rectangular and covers $70 \mathrm{~km}$ of the coastal area with the Civitavecchia port located at the center. Neumann boundary conditions were applied on the cross-shore boundaries in combination with a water-level boundary on the seaward side, which is necessary to ensure that the solution of the mathematical boundary value problem is well posed. Since small errors may occur near the boundaries, the study area was positioned away from the side of the model domain. The hydrodynamic equations were solved on a finite difference curvilinear grid with approximately 39000 elements. In order to limit computational requirements, a different resolution was applied in the model domain extending from $15 \times 15 \mathrm{~m}$ in the Civitavecchia harbor area to $300 \times 300 \mathrm{~m}$ near the seaward boundary. The water column was subdivided into 10 sigma layers with a uniform thickness to ensure sufficient resolution in the nearcoastal zone.

Since dynamical processes occurring in coastal areas are modulated by wind and wave conditions (tidal forcing was neglected because it does not exceed $0.40 \mathrm{~m}$ over the simulation periods), the hydrodynamic field was obtained by coupling the DELFT3D-FLOW with SWAN that uses the same computational grid. Wind data collected by WS were used to feed DELFT3D-FLOW, and the wave parameters acquired by WB1 (offshore wave buoy) were employed to generate the JONSWAP wave spectra (Hasselmann et al., 1980) as boundary conditions of the SWAN model.

To resolve the turbulent scale of motion, the values of horizontal background eddy viscosity and diffusivity were both set equal to $1 \mathrm{~m}^{2} \mathrm{~s}^{-1}$ (Briere et al., 2011), and the $k-\varepsilon$ turbulence closure model was taken into account (Launder and Spalding, 1974). To assign the spatial patterns of physical and biological parameters as initial conditions of DELFT3DWAQ, the satellite observations in the offshore zone and the WQS measures in the nearshore one were used, respectively. These data were integrated into the water quality model by applying the DINEOF technique (Beckers et al., 2006; Volpe et al., 2012) that reconstructs the missing data along the coast and in the areas affected by clouds.

Since the pollutant dispersion represents the C-CEMS results, the capability of the observation system in reproducing the output of coastal pressures was evaluated by comparing the model results with sea currents (WQB) and wave (WB2) data.

The performance of the hydrodynamic models (DELFT3D-FLOW and SWAN) was evaluated using the relative mean absolute error (RMAE) and the associated qualitative ranking (excellent, good, reasonable, and poor; Van Rijn et al., 2003).

The marine currents resulting from the coupling between DELFT3D-FLOW and SWAN were compared with in situ measurements collected by WCS from 13 to 18 January 

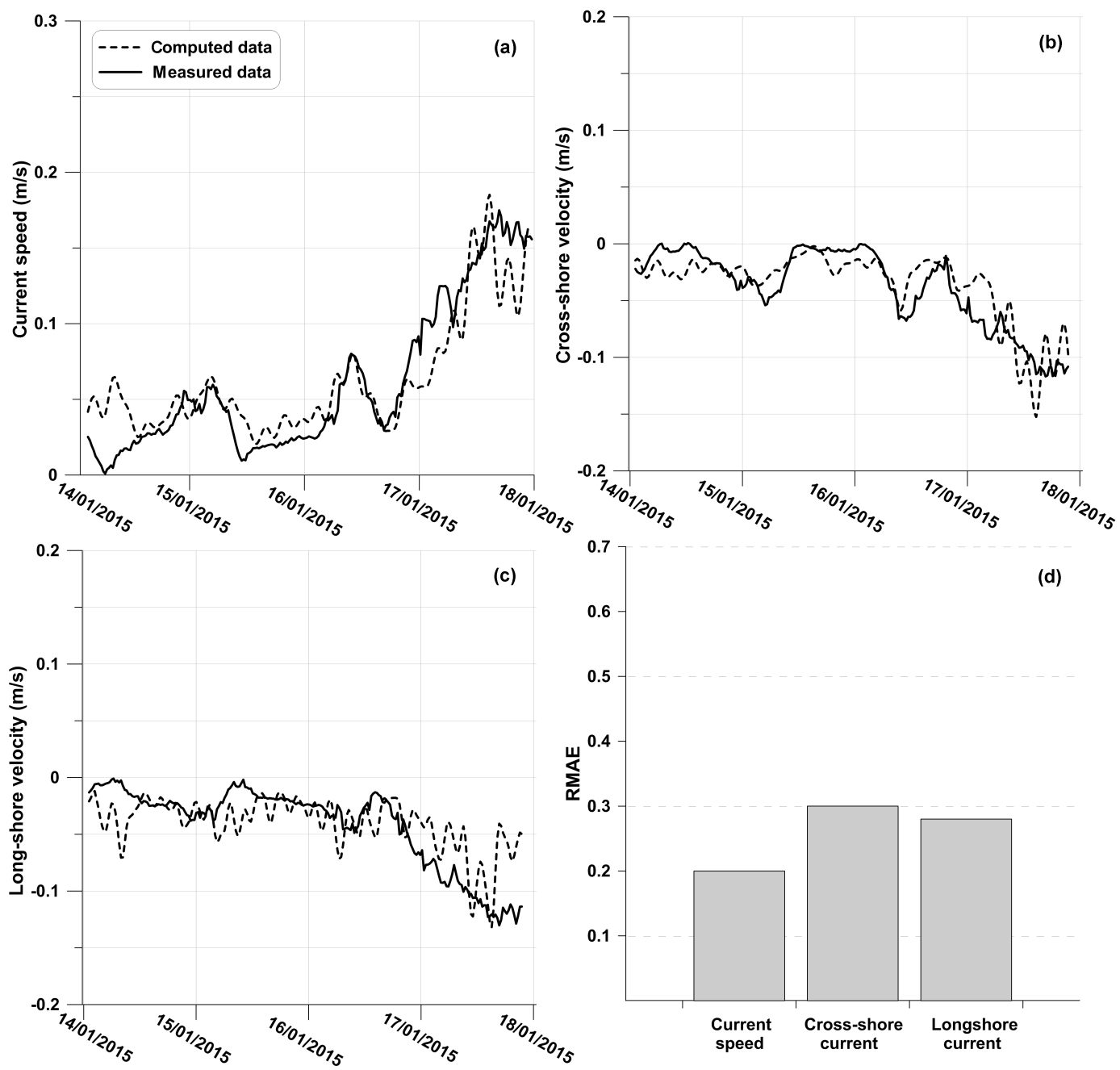

Figure 3. Validation of current-speed (a), cross-shore (b), and along-shore (c) components. The solid and dotted lines represent the measured and computed time series, respectively. Statistics (RMAE) for current-speed, cross-shore, and along-shore components are reported in (d).

2015. The velocity magnitude was reproduced with a "good" accuracy since the RMAE value was less than 0.2. The longshore and cross-shore components of the marine currents exhibited a higher RMAE: 0.28 and 0.3 , respectively. The validation of current speed, cross-shore, and along-shore components is shown in Fig. 3.

The performance of the SWAN model was evaluated using data acquired by the WB2. We calculated the RMAE both for the entire data set and for three wave direction intervals: $139-198^{\circ} \mathrm{N}$ (first interval), $198-257^{\circ} \mathrm{N}$ (second interval), and $257-316^{\circ} \mathrm{N}$ (third interval). Considering the entire data set, the wave height was accurately simulated (RMAE $<0.1$ ), but the model error changed significantly on the basis of the wave direction: the RMAE was higher between 139 and $198^{\circ} \mathrm{N}(0.26$; reasonable agreement $)$ and lower in the second and third intervals $(<0.01$; excellent agreement), as reported in Fig. 4.

\section{C-CEMS applications}

To test the capabilities of C-CEMS in defining the areas mainly affected by pollutant dispersion, we considered two case studies that concerned the potential effects produced by untreated wastewater discharge and dredging activities (coastal pressures) on bathing areas and SCIs (sensitivity areas), respectively. For both cases, two scenarios with different weather conditions were considered: one reproduced a low wind intensity and low wave height (low condition, LC), and the other simulated a strong high wind speed and high wave height (high condition, HC).

\subsection{Bacterial dispersion in bathing areas}

The presence of pathogenic bacteria in seawater may cause several illnesses including skin infections and dangerous gastrointestinal diseases (Cabelli et al., 1982; Cheung et al., 


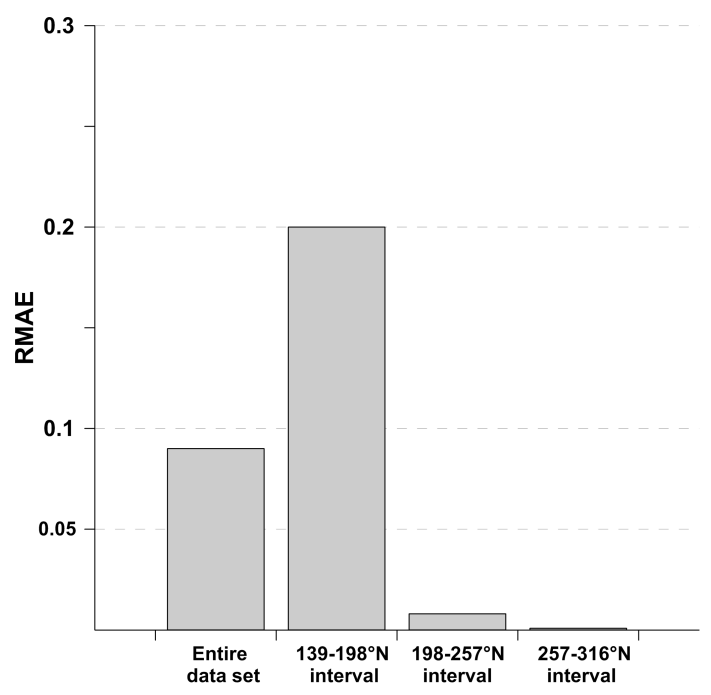

Figure 4. Validation of the SWAN model using RMAE values calculated both for the entire data set and for three wave direction intervals.

1990; Calderon et al., 1991; McBride et al., 1998; Haile et al., 1999; Colford et al., 2007).

The probability of human infection depends on the exposure time and the concentration of the bacterial load in bathing areas. These parameters are linked to the presence of untreated wastewater discharge in the study area and the local hydrodynamical (currents and waves) and environmental (salinity, temperature, and solar radiation) conditions. Among the bacteria that can damage the health of bathers, Escherichia coli, a Gram-negative enteric bacteria present in the feces of humans and warm-blooded animals, is considered to be an indicator of water quality. Although the pathogenic bacteria are neglected by MSFD, microbes are relevant to several GES descriptors, notably Descriptor 1 (D1, Biological Diversity), Descriptor 4 (D4, Foodwebs), Descriptor 5 (D5, Eutrophication), and Descriptor 8 (Contaminants; Caruso, 2014; Caruso et al., 2015). However, controlling water quality in bathing waters is required by national (Legislative Decree 116/2008) and community environmental directives (2006/7/EC).

Within the framework of C-CEMS to perform fecal pollution monitoring, in situ water samplings were carried out weekly during the summer of 2012 at the discharge points indicated in Fig. 1c to analyze the abundance of E. coli according to standard culture methods (APAT CNR, 2003).

To define the zones mainly affected by the dispersion of pathogenic bacteria in the Civitavecchia bathing area, we used the Microbiological Potential Risk Area (MPRA), defined as the area over which the $E$. coli concentration is greater than or equal to $1 \%$ of the concentration measured at a discharge point (Bonamano et al., 2015a). The dispersion of $E$. coli was simulated by DELFT3D-WAQ using the mean bacterial concentration measured during the summer at the discharge points. This model shows a good performance in reproducing the bacterial load concentration near the discharge points (Zappalà et al., 2015). The LC and HC simulations that last 2 days were set to occur on August weekends when the beaches are characterized by a larger number of bathers. The distribution of bacterial concentration over the study area calculated by DELFT3D-WAQ depended on the hydrodynamic field obtained from the coupling between DELFT3D-FLOW and SWAN and on the decay rate proposed by Thoe (2010). It was calculated using the salinity acquired by WQS1, WQS2 and WQB, and the surface solar radiation measured by WS, TSM and SST obtained by the integration between satellite observations and WQS station data.

The E. coli concentration calculated near the discharge points was high when low marine currents (LC) were present, as reported in Fig. 5a. In particular, the area around the PI18 point exhibited maximum values of pathogenic bacteria because of the slow dilution of contaminated waters in that area. During intense weather conditions (HC), the E. coli concentration near the discharge points was lower than that calculated in the LC simulation. However, the bacterial load was distributed over a more extended area, as reported in Fig. 5b. In both simulations, the dispersion of $E$. coli did not affect the bathing area located to the south of the study area.

\subsection{Dredged sediment dispersion on Posidonia oceanica meadows}

As previously reported, the port of Civitavecchia was subjected to extensive dredging between 1 November 2012 and 31 January 2013. During the first phase of the project, the dredging of the channel to access the port of Civitavecchia was conducted by deepening the seabed to a depth of $-17 \mathrm{~m}$ above mean sea level over an area of approximately $31000 \mathrm{~m}^{2}$. In the ferry dock area, the seabed reached a depth of $-10 \mathrm{~m}$ over an area of approximately $123650 \mathrm{~m}^{2}$ and $-15 \mathrm{~m}$ over an area of approximately $51900 \mathrm{~m}^{2}$. The total dredging volume was approximately $918000 \mathrm{~m}^{3}$.

Studying sediment resuspension caused by these dredging activities is critical because of its role in the dispersion of particulate matter in the adjacent marine environment in both the sediment and water (Van den Berg et al., 2001). Within MSFD, turbidity due to fine sediment dispersion is an indicator reported in Descriptor 1 (D1, Biological biodiversity), Descriptor 5 (D5, Eutrophication) and Descriptor 7 (Hydrographical condition). In this study, we considered two out of the four SCIs coded as IT60000005 (434.47 ha) and IT60000006 (745.86 ha) localized in the north and the south of the Civitavecchia harbor, as shown in Fig. 1b. Since Posidonia oceanica makes up most of the SCIs, the study was focused on the effects of dredging activities on the seagrass status. Dredging-induced suspended sediment transport and deposition may have direct and indirect impacts on this seagrass, such as reducing the underwater light penetration and 


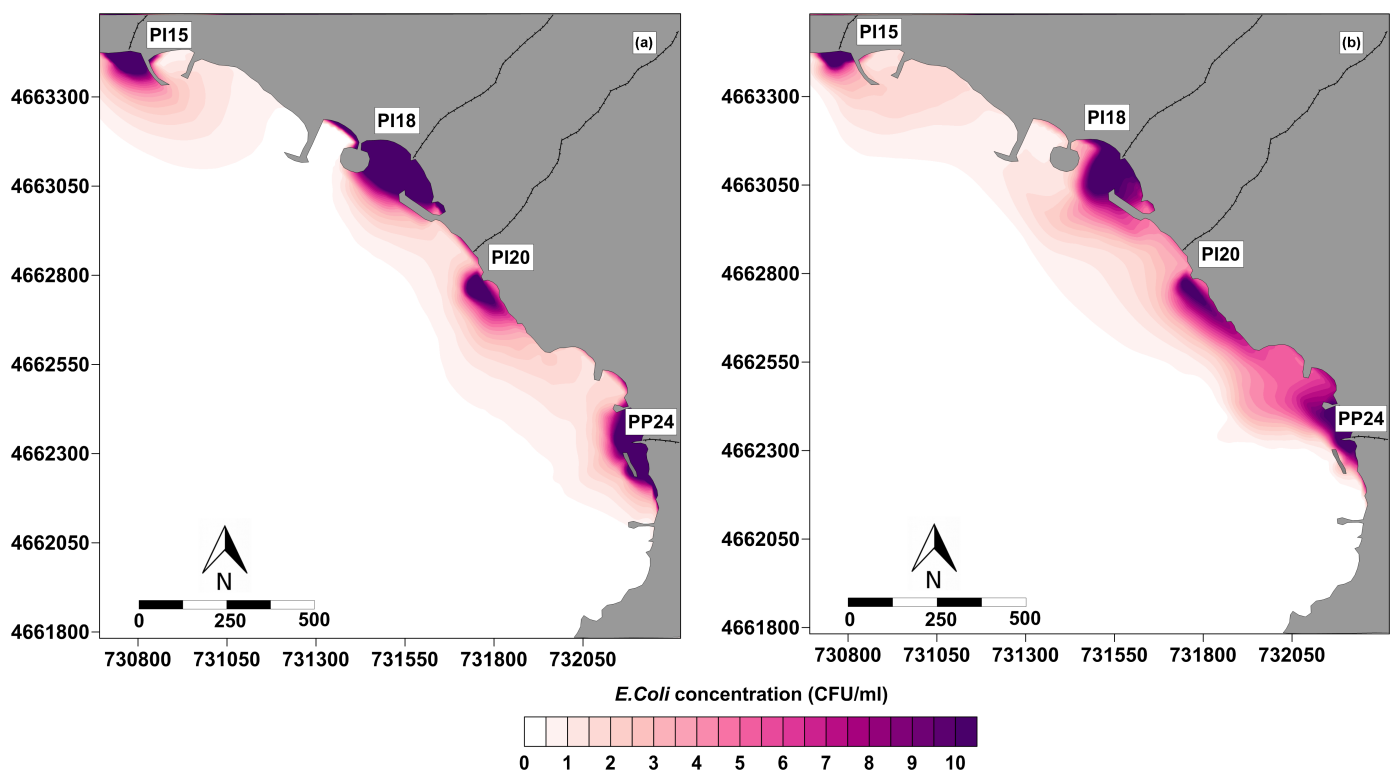

Figure 5. LC (a) and HC (b) simulation results of the bacterial dispersion in the Civitavecchia bathing areas. The distribution of $E$. coli concentration refers to the end of the simulation period.

producing the burial of the shoot apical meristems, respectively. The plant survival can be compromised if the light availability is less than 3-8\% of SI (Erftemeijer and Lewis, 2006) or if low-light conditions persist for more than 24 months (Gordon et al., 1994). The survival rates of Posidonia oceanica can also be reduced if the sedimentation rate exceeds $5 \mathrm{~cm}$ per year (Manzanera et al., 1995).

The health status of Posidonia oceanica meadows located in the two SCIs was evaluated by a shoot density descriptor. This parameter was acquired by scuba divers in the late spring of 2013 in correspondence with 14 stations (3 in IT6000005 and 11 in IT6000006) following the method reported in Buia et al. (2003). The thematic map was obtained by spatially interpolating the data collected in the two areas.

The potential impact due to dredging activities was evaluated by DELFT3D-WAQ simulations assuming a continuous release of fine sediments $(<0.063 \mathrm{~mm})$ in the northern zone of Civitavecchia harbor. The amount of material released during dredging was calculated using a formula from Hayes and $\mathrm{Wu}$ (2001) with a resuspension factor of $0.77 \%$, typical of hydraulic dredges (Anchor Environmental, 2003). The percentage of fine sediment fraction was $8.87 \%$, and its density was $2650 \mathrm{~kg} \mathrm{~m}^{-3}$ according to sedimentological data collected in the area affected by the dredging works. Considering also that the dredging operations lasted approximately 3 months (from November 2012 until January 2013), a continuous release of $0.314 \mathrm{~kg} \mathrm{~s}^{-1}$ was assumed. TSM distribution, obtained by the integration between satellite observations and WQB data, was used as a proxy of spatial variation of fine sediment concentration in the study area to provide the initial conditions of DELFT3D-WAQ. The transport, deposi- tion, and resuspension processes associated with the fine particles were reproduced taking into account a settling velocity of approximately $0.25 \mathrm{~m} \mathrm{day}^{-1}$, a critical shear for sedimentation of $0.005 \mathrm{~N} \mathrm{~m}^{-2}$, and a critical shear for resuspension of $0.6 \mathrm{~N} \mathrm{~m}^{-2}$ (Alonso, 2010). The DELFT3D-WAQ simulations were run over the periods 26 November 2012 through 3 December 2012 (HC simulation) and 3-10 January 2013 (LC simulation). These time intervals included the dredging period.

Like the analysis of bacterial dispersion, the fate of dredged sediments within the study area was evaluated over an area in which the suspended solid concentration was greater than or equal to $1 \%$ of the value estimated at the source point. This area was referred to as the Dredging Potential Impact Area (DPIA). The results of the LC simulation, reported in Fig. 6a, revealed that the dredged suspended materials were transported into the southern zone of the study area, achieving a maximum distance of approximately $2 \mathrm{~km}$ from the dredging point. In the HC simulation reported in Fig. 6b, the dredged sediment dispersion moved toward the north, with a higher concentration in the nearshore zone. Although the sediment plume extended $20 \mathrm{~km}$ from the source, higher values of suspended solid concentration only affected the Posidonia oceanica meadow closer to the harbor (the southern part of SCI IT 6000005; Bonamano et al., 2015b).

\section{Discussion}

In the last 2 decades, the importance of integrated ocean observing systems, providing observations, numerical models and software infrastructures, has been widely recognized, not 


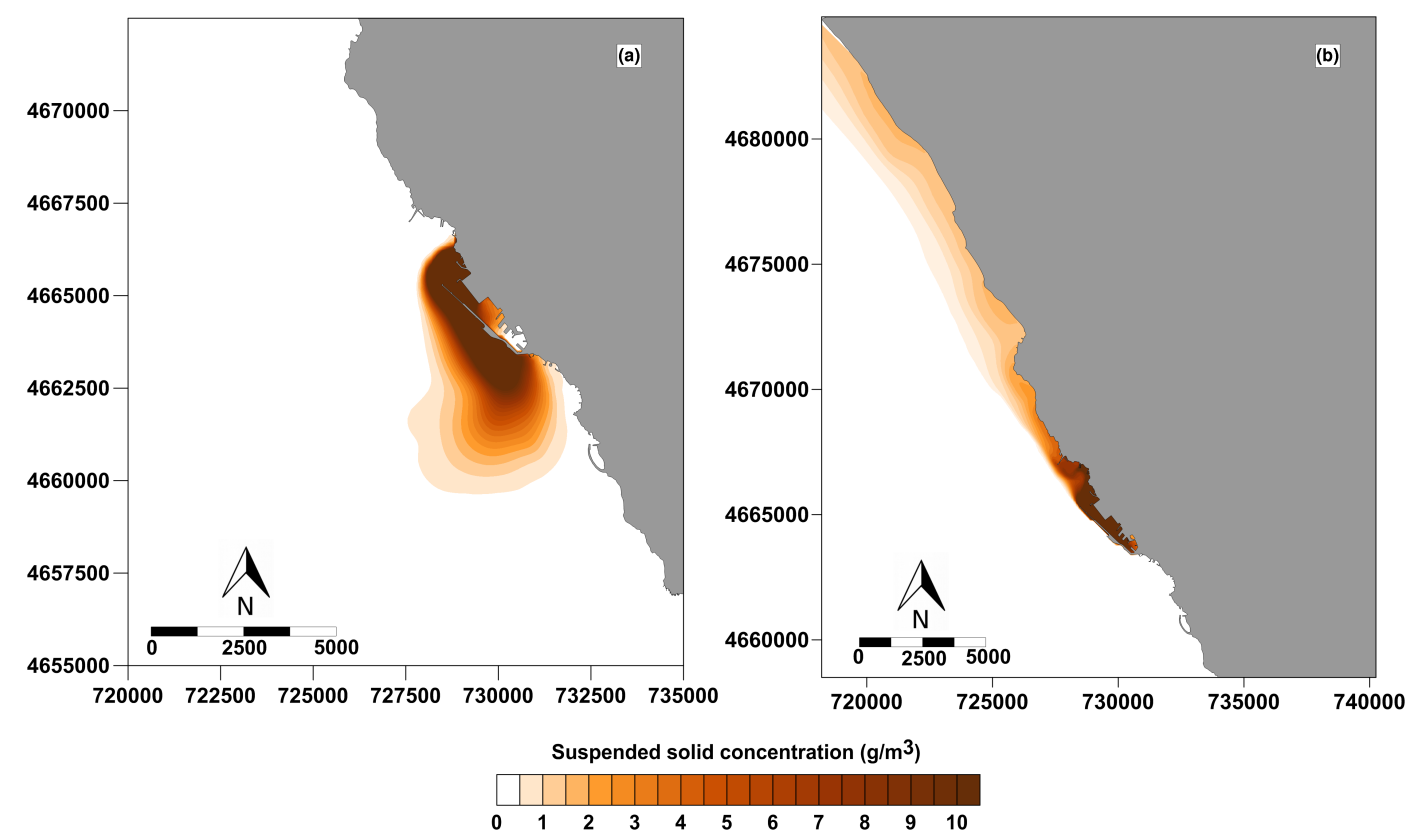

Figure 6. LC (a) and HC (b) simulation results of the dispersion of dredged materials in the study area. The distribution of fine sediment concentration refers to the end of the simulation period.

only for scientific purposes, but also for supporting societal needs such as the management of marine resources and the mitigation of anthropic pressures through specific planning (Siddorn et al., 2007; Weisberg et al., 2009; Tintoré, 2013; Sayol et al., 2014). Especially in coastal environments where unpredictable pollution phenomena often occur, the setup of multi-platform observing systems represents an important step towards the analysis and forecasting of the impacts on both environmental and socio-economical resources, overcoming the difficulties of the traditional approach (Schofield et al., 2002), which does not allow a proper identification.

To this aim, C-CEMS was implemented in 2005 along the coast of Civitavecchia, a highly populated area characterized by the coexistence of industrial and human pressures with environmental resources and values. It integrates fixed stations, in situ surveys and satellite observations that ensure the availability of a large amount of data allowing one to detect pollution phenomena. Moreover, C-CEMS provides an ecosystem-based monitoring tool for the analysis and forecasting of the coastal conflicts thanks to the use of mathematical models. Kourafalou et al. (2015) highlighted the need to support the advancement of coastal forecasting systems integrating the observational and modeling components in order to analyze the high spatial and temporal variability of coastal processes. The results of the hydrodynamic model validation with sea currents (WCS) and wave (WB2) data show how CCEMS is able to reproduce accurately the output of coastal pressures in terms of pollutant dispersion. DELFT3D-FLOW reproduces with good accuracy the velocity components of marine currents, while SWAN calculates the wave height in the nearshore area with a higher skill when the interval direction is $198-316^{\circ} \mathrm{N}$. On the contrary, when the wave direction ranges between 139 and $198^{\circ} \mathrm{N}$, the capacity of the model is more affected by the increase in diffraction processes due to the Civitavecchia harbor breakwater.

Two examples of C-CEMS capacity to provide information related to some of the most pressing conflicts facing our coastal zone, such as "urban discharge - bathing area" and "dredging - SCI", have been reported in this study. The application of C-CEMS to these case studies allowed one to define the output of human activities by the use of potentially polluting zoning indicators such as MPRA and DPIA, giving the potential impacts produced by pathogenic bacteria and dredged fine sediment on sensitivity areas under different weather conditions (HC and LC). The overlap of the model results with the thematic maps of the sensitivity areas enabled the detection of the coastal areas affected by conflicts. In the first case, the overlap of MPRAs calculated in the LC and $\mathrm{HC}$ scenarios shows that most of the bathing areas were affected by a high level of bacterial contamination (Fig. 7a). Maximum values of E.coli abundance were found near the PI18 and PP24 discharges because the dilution of the contaminated waters was inhibited by the presence of artificial barriers. These unfavorable conditions may cause risks to human health related to the contamination from potentially infectious microorganisms for bathers. As a result, the bathing facilities located within this zone were at risk of suffering significant economic losses. However, the southern bathing area, where more bathers are found, was never affected by E. coli dispersion (Fig. 7a). In the second case study, the 


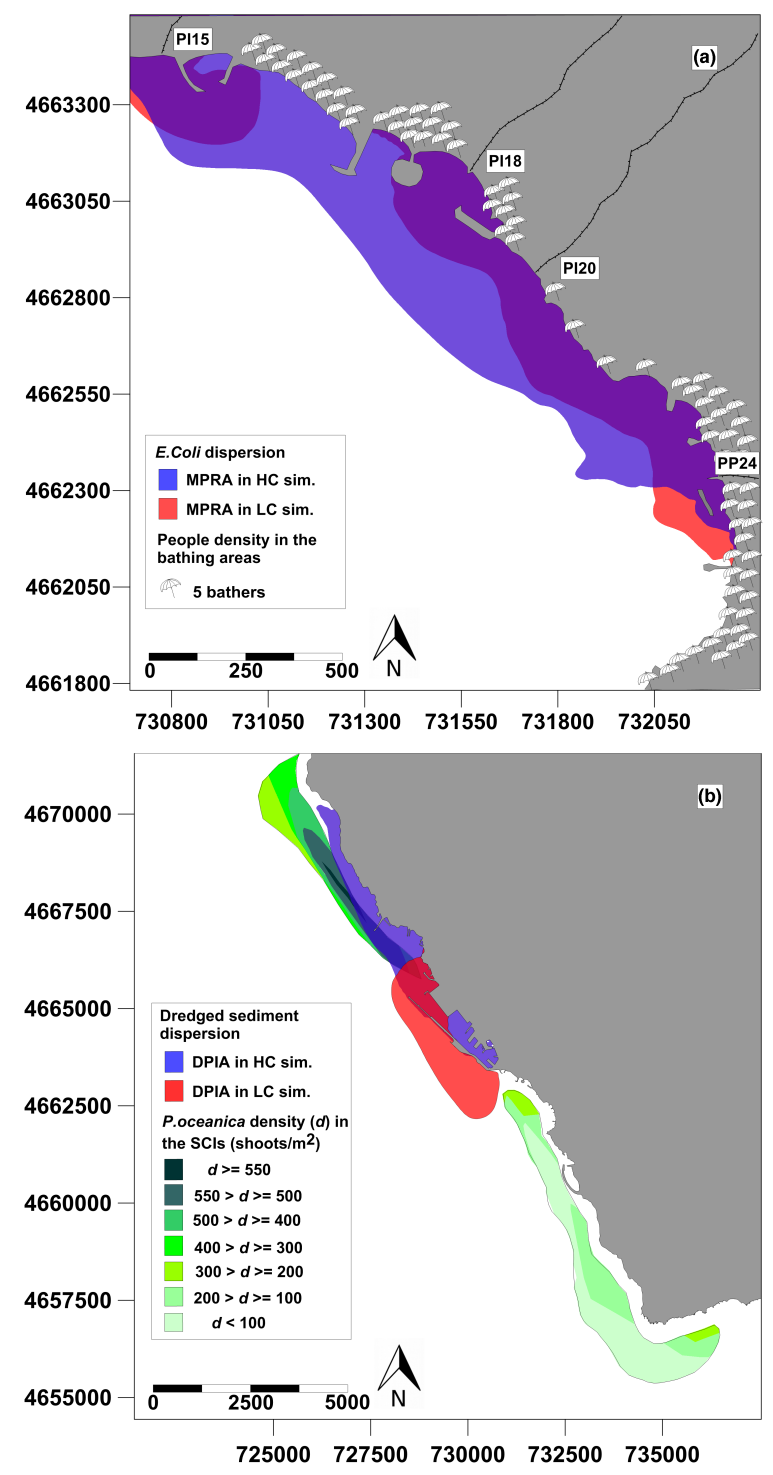

Figure 7. Overlap between anthropic pressures indicated by the potentially polluting zoning indicators (MPRA and DPIA) and sensitivity areas represented as thematic maps to analyze urban discharge bathing area (a) and dredging SCI (b) conflicts.

simulation results differ among the LC and $\mathrm{HC}$ scenarios (Fig. 7b). In the LC scenario, DPIA does not overlap the southern SCI (IT 6000006), even though the seagrass meadows were characterized by poorer health than in the northern SCI. In HC, DPIA includes a restricted zone of Posidonia oceanica meadow ( $98.84 \mathrm{ha})$ in the northern SCI, closer to Civitavecchia harbor, characterized by high shoot density values (between 400 and 550 shoots $\mathrm{m}^{-2}$ ). A previous study (Bonamano et al., 2015b) showed that after the dredging activities the shoot density values were slightly higher than before, highlighting how this conflict did not produce a loss of environmental resources.
These results show how C-CEMS works to give a rapid environmental assessment enabling one to analyze the impacts and potential mitigation practices when an user-environment conflict is detected. If there are no conflicts, the system still provides integrated information for the sustainable management of the coastal zone as requested by IMP for the EU.

To make C-CEMS more effective, a flexible X-Band Radar system to continuously measure the sea state (surface currents and wave field) in the nearshore zone (Serafino et al., 2012) has been recently integrated. Moreover, to improve the resolution of multi-spectral imagery in the study area, C-CEMS will soon be available to get data also from the Sentinel-2 mission.

Since coastal marine ecosystems have been acknowledged to provide the most benefits among all terrestrial and marine ecosystems (Costanza et al., 1997), the assignment of an economic value to these natural resources is essential for correct planning of marine coastal areas. The last step toward in adequate management and conservation of marine environmental resources concerns the implementation of C-CEMS for the quantification of economic impacts in terms of losses of ecosystem services and goods.

Compared to other regional operational monitoring systems currently available and reported in the literature, the practical innovation offered by the C-CEMS relies on the fact that this new system allows one to detect the impacts arising from the potential conflicts between coastal pressures and sensitivity areas; in this sense, C-CEMS can be considered an operational tool to meet the needs of MSFD and MSP directives.

\section{Conclusions}

The activities and techniques employed are in line with those used in several environmental monitoring experiences; what really is new is their integration into an operational network, the first in the Tyrrhenian Sea, actually used by a professional stakeholder such as the Port Authority of Civitavecchia.

Coastal observatories play a major role in providing the information needed to face the new European environmental challenges mainly focused on the GES achievement and MSP implementation. Thanks to the integration of different observing platforms at different scales, and to the provision of data and tools, these systems contribute to the monitoring of coastal pressures and environmental states. C-CEMS has been conceived to include all the above-mentioned features to support the coastal management about the detection of the conflicts between anthropic pressure and sensitivity areas. Such information overlapped with the characteristics of coastal marine ecosystems intended for recreational uses can be considered to be the first step in the establishment of the marine functional zoning scheme made by different types of zones with varying levels of limited uses (Douvere, 2008). 
Acknowledgements. The authors thank the Environmental Office of the Civitavecchia Port Authority for funding the implementation of C-CEMS. The authors are also thankful to two anonymous reviewers for providing useful comments that helped in improving a former version of this paper. Finally, the authors acknowledge the NOAA CoastWatch program and NASA's Goddard Space Flight Center, OceanColor Web, for data availability.

Edited by: V. Brando

\section{References}

Alonso, J.: Heavy metal pollution and sediment transport in the rhinemeuse estuary, using a 2-D model Delft3D: Water quality and calamities, Case study Biesbosch, Delft Cluster, Delft, the Netherlands, 1-53, 2010.

Anchor Environmental: Literature review of effects of resuspended sediments due to dredging operations, Prepared for Los Angeles Contaminated Sediments Task Force, Los Angeles, CA, 1-140, 2003.

APAT-CNR-IRSA: Manuali e Linee Guida, Metodi Analitici per le Acque 29/2003, III; sezione 6000 Metodi microbiologici - parte generale; sezione 7000 Metodi per la determinazione dei microrganismi indicatori di inquinamento e di patogeni, Rome, Italy, 883-894, 2003.

Beckers, J. M., Barth, A., and Alvera-Azcárate, A.: DINEOF reconstruction of clouded images including error maps - Application to the sea-surface temperature around Corsican Island, Ocean Sci., 2, 183-199, 2006.

Bigongiari, N., Cipriani, L. E., Pranzini, E., Renzi, M., and Vitale, G.: Assessing shelf aggregate environmental compatibility and suitability for beach nourishment: A case study for Tuscany (Italy), Mar. Poll. Bull., 93, 183-193, 2015.

Bonamano, S., Madonia, A., Borsellino, C., Stefanì, C., Caruso, G., De Pasquale, F., Piermattei, V., Zappalà, G., and Marcelli, M.: Modeling the dispersion of viable and total Escherichia coli cells in the artificial semi-enclosed bathing area of Santa Marinella (Latium, Italy), Mar. Poll. Bull., 95, 141-154, 2015a.

Bonamano, S., Paladini de Mendoza, F., Piermattei, V., Martellucci, R., Madonia, A., Gnisci, V., Mancini, E., Fersini, G., Burgio, C., Marcelli, M., and Zappalà, G.: Mathematical models supporting the monitoring of Civitavecchia harbour near Rome, Computational Methods and Experimental Measurements XVII, 59, 443453, 2015b.

Booij, N., Ris, R. C., and Holthuijsen, L. H.: A third-generation wave model for coastal regions, Part I: Model description and validation, J. Geophys. Res., 104, 7649-7666, 1999.

Briere, C., Giardino A., and van der Werf, J.: Morphological modeling of bar dynamics with DELFT3d: the quest for optimal free parameter settings using an automatic calibration technique, Coastal Engineering Proceedings: sediment, 1, 1-12, 2011.

Buia, M. C., Gambi, M. C., and Dappiano, M.: I sistemi a fanerogame marine, in: Manuale di Metodologie di campionamento e studio del benthos marino mediterraneo, edited by: Gambi, M. C. and Dappiano, M., Biol. Mar. Med, 19, 145-198, 2003.
Cabelli, V. J., Dufour, A. P., McCabe, L. J., and Levin, M. A.: Swimming-associated gastroenteritis and water quality, Am. J. Epidemiol., 115, 606-616, 1982.

Calderon, R. L., Mood, E. W., and Dufour, A. P.: Health effects of swimmers and nonpoint sources of contaminated water, Int. J. Environ. Health Res., 1, 21-31, 1991.

Cappucci, S., Scarcella, D., Rossi, L., and Taramelli, A.: Integrated coastal zone management at Marina di Carrara Harbor: sediment management and policy making, Ocean Coast. Manage., 54, 277-289, 2011.

Caruso, G.: Marine Strategy Framework Directive: Current Gaps in Microbiological Issues, J, Ecosys. Ecograph., 4, e120, doi:10.4172/2157-7625.1000e120, 2014.

Caruso, G., La Ferla, R., Azzaro, M., Zoppini, A., Marino, G., Petochi, T., Corinaldesi, C., Leonardi, M., Zaccone, R., Fonda Umani, S., Caroppo, C., Monticelli, L. S., Azzaro, F., Decembrini, F., Maimone, G., Cavallo, R. A., Stabili, L., Todorova, N. H., Karamfilov, V. K., Rastelli, E., Cappello, S., Acquaviva, M. I., Narracci, M., De Angelis, R., Del Negro, P., Latini, M., and Danovaro, R.: Microbial assemblages for environmental quality assessment: knowledge, gaps and usefulness in the European Marine Strategy Framework Directive, Crit. Rev. Microbiol., 122, doi:10.3109/1040841X.2015.1087380, 2015.

Cheung, W., Chang, K., Hung, R., and Kleevens, J.: Health effects of beach water pollution in Hong Kong, Epidemiol. Infect., 105 , 139-162, 1990.

Cheung, Y. H. and Wong, M. H.: Toxic effects of dredged sediments of Hong Kong coastal waters on clams, Environ. Technol., 14, 1047-1055, 1993.

Colford, J. M., Wade, T. J., Schiff, K. C., Wright, C. C., Griffith, J. F., Sandhu, S. K., Burns, S., Sobsey, M., Lovelace, G., and Weisberg, S. B.: Water quality indicators and the risk of illness at beaches with nonpoint sources of fecal contamination, Epidemiology, 18, 27-35, 2007.

Costanza, R., d'Arge, R., de Groot, R. S., Farber, S., Grasso, M., Hannon, B., Limburg, K., Naeem, S., O’Neill, R., Paruelo, J., Raskin, R., Sutton, P., and van den Belt, M.: The value of the world's ecosystem services and natural capital, Nature 387, 253260, 1997.

Council Directive: 92/43/EEC of 21 May 1992 on the conservation of natural habitats and of wild fauna and flora, Official Journal, L 206/7, 1992.

Crise, A., Kaberi, H., Ruiz, J., Zatsepin, A., Arashkevich, E., Giani, M., Karageorgis, A. P., Prieto, L., Pantazi, M., GonzalezFernandez, D., Ribera d'Alcalà, M., Tornero, V., Vassilopoulou, V., Durrieu de Madron, X., Guieu, C., Puig, P., Zenetos, A., Andral, B., Angel, D., Altukhov, D., Ayata, S. D., Aktan, Y., Balcıoğlu, E., Benedetti, F., Bouchoucha, M., Buia, M. C., Cadiou, J.-F., Canals, M., Chakroun, M., Christou, E., Christidis, M. G., Civitarese, G., Coatu, V., Corsini-Foka, M., Cozzi, S., Deidun, A., Dell'Aquila, A., Dogrammatzi, A., Dumitrache, C., Edelist, D., Ettahiri, O., Fonda-Umani, S., Gana, S., Galgani, F., Gasparini, S., Giannakourou, A., Gomoiu, M.-T., Gubanova, A., Gücü, A.-C., Gürses, Ö., Hanke, G., Hatzianestis, I., Herut, B., Honey, R., Huertas, E., Irisson, J.-O., Isinibilir, M., Jimenez, J. A., Kalogirou, S., Kapiris, K., Karamfilov, V., Kavadas, S., Keskin, Ç., Kideys, A. E., Kocak, M., Kondylatos, G., Kontogiannis, C., Kosyan, R., Koubbi, P., Kušpilic, G., La Ferla, R., Langone, L., Laroche, S., Lazar, L., Lefkaditou, E., Lemeshko, 
I. E., Machias, A., Malej, A., Mazzocchi, M.-G., Medinets, V., Mihalopoulos, N., Miserocchi, S., Moncheva, S., Mukhanov, V., Oaie, G., Oros, A., Öztürk, A. A., Öztürk, B., Panayotova, M., Prospathopoulos, A., Radu, G., Raykov, V., Reglero, P., Reygondeau, G., Rougeron, N., Salihoglu, B., Sanchez-Vidal, A., Sannino, G., Santinelli, C., Secrieru, D., Shapiro, G., Simboura, N., Shiganova, T., Sprovieri, M., Stefanova, K., Streftaris, N., Tirelli, V., Tom, M., Topaloglu, B., Topçu, N. E., Tsagarakis, K., Tsangaris, C., Tserpes, G., Tugrul, S., Uysal, Z., Vasile, D., Violaki, K., Xu, J., Yüksek, A., and Papathanassiou, E.: A MSFD complementary approach for the assessment of pressures, knowledge and data gaps in Southern European Seas: The PERSEUS experience, Mar. Pollut. Bull., 95, 28-39, 2015.

Cristina, S., Icely, J., Goela, P. C., DelValls, T. A., and Newton, A.: Using remote sensing as a support to the implementation of the European Marine Strategy Framework Directive in SW Portugal, Cont. Shelf Res., 108, 169-177, 2015.

Cui, T., Zhang, J., Tang, J., Sathyendranath, S., Groom, S., Ma, Y., Zhao, W, and Song, Q.: Assessment of satellite ocean color products of MERIS, MODIS and SeaWiFS along the East China Coast (in the Yellow Sea and East China Sea), ISPRS J. Photogramm. Remote Sens., 87, 137-151, 2014.

Cutroneo, L., Massa, F., Castellano, M., Canepa, G., Costa, S., Povero, P., Tucci, S., and Capello, M.: Technical and public approaches to involve dredging stakeholders and citizens in the development of a port area, Environ. Earth Sci., 72, 3159-3171, 2014.

Decision 140/2007: Deliberazione 21 dicembre 2007, no. 140, Potenziamento "hub" portuale di Civitavecchia, nell' ambito del programma delle infrastrutture strategiche (legge no. 443/2001), Prolungamento antemurale C. Colombo e Darsena traghetti, Gazzetta Ufficiale della Repubblica italiana, 140, 50-54, 2008.

Directive 2006/7/EC of the European Parliament and of the Council of 15 February 2006 concerning the management of bathing water quality and repealing Directive 76/160/EEC, Official Journal of the European Union, L 64/37, 37-51, 2006.

Directive 2008/56/EC of the European Parliament and of the Council of 17 June 2008, establishing a framework for community action in the field of marine environmental policy (Marine Strategy Framework Directive), Official Journal of the European Union L164, Official Journal of the European Union, L 164/19, 19-40, 2008.

Directive 2014/89/EU of the European Parliament and of the Council of 23 July 2014 establishing a framework for maritime spatial planning, Official Journal of the European Union, L 257/135, 135-145, 2014.

Decreto Legislativo 30 maggio 2008, n. 116, Attuazione della direttiva 2006/7/CE relativa alla gestione della qualità delle acque di balneazione e abrogazione della direttiva 76/160/CEE, Gazzetta Ufficiale della Repubblica italiana, no. 155, 4-15, 2008.

Douvere, F.: The importance of marine spatial planning in advancing ecosystem-based sea use management, Mar. Policy, 32, 762771,2008

Drusch, M., Del Bello, U., Carlier, S., Colin, O., Fernandez, V., Gascon, F., Hoersch, B., Isola, C., Laberinti, P., Martimort, P., Meygret, A., Spoto, F., Sy, O., and Marchese, F.: Sentinel-2: ESA's optical high-resolution mission for GMES operational services, Remote Sens. Environ., 120, 25-36, 2012.
Erftemeijer, P. L. A. and Lewis, R. R. R.: Environmental impacts of dredging on seagrasses: A review, Mar. Pollut. Bull., 52, 15531572, 2006.

Filipponi, F., Taramelli, A., Zucca, F., Valentini, E., and El Serafy, G. Y.: Ten-years sediment dynamics in Northern Adriatic sea investigated through optical remote sensing observations, In Geoscience and Remote Sensing Symposium (IGARSS), 2015 IEEE International, 2265-2268, 2015.

Glasgow, H. B., Burkholder, J. M., Reed, R. E., Lewitus, A. J., and Kleinman, J. E.: Real-time remote monitoring of water quality: a review of current applications, and advancements in sensor, telemetry, and computing technologies, J. Exp. Mar. Bio. Ecol., 300, 409-448, 2004.

Glenn, S. M., Dickey, T. D., Parker, B., and Boicourt, W.: Long term real-time coastal ocean observation networks, Oceanography, 13, 24-34, 2000.

Gordon, D. M., Grey, K. A., Chase, S. C., and Simpson, C. J.: Changes to the structure and productivity of a Posidonia sinuosa meadow during and after imposed shading, Aquat. Bot., 47, 265-275, 1994.

Haidvogel, D. B., Blanton, J., Kindle, J. C., Lynch, D. R.: Coastal ocean modeling: Processes and real-time systems, Oceanography, 13, 35-46, 2000.

Haile, R. W., White, J. S., Gold, M. R., Cressey, C., McGee, R. C., Millikan, A., Glasser, N., Harawa, C., Ervin, P., Harmon, J., Harper, J., Dermand, J., Alamillo, K., Barrett, M., Nides, G., and Wang, Y.: The health effects of swimming in ocean water contaminated by storm drain runoff, Epidemiology, 10, 355-363, 1999.

Hart, J. K. and Martinez, K.: Environmental Sensor Networks: A revolution in the earth system science?, Earth-Sci. Rev., 78, 177191, 2006.

Hasselmann, D. E., Dunckel, M., and Ewing, J. A.: Directional wave spectra observed during JONSWAP 1973, J. Phys. Oceanogr., 10, 1264-1280, 1980.

Hayes, D. and Wu, P. Y.: Simple approach to TSS source strength estimates, in: Proceedings of the WEDA XXI Conference, Houston, TX, USA, 25-27 June 2001.

Hopkins, T. S.: Recent observation on the intermediate and deep water circulation in the southern Tyrrhenian Sea, Oceanol. Acta, 9, 41-50, 1988.

ISO/Ts 19139: 2007 Geographic information - Metadata - XML schema implementation, International Organization for Standardization, Geneva, Switzerland, 1-111, 2007.

ISO 19115-1: 2014 Geographic information - Metadata - Part 1: Fundamentals, International Organization for Standardization, Geneva, Switzerland, 2014.

Jayasinghe, R. P. K., Amarasinghe, U. S., and Newton, A.: Evaluation of marine subareas of Europe using life history parameters and trophic levels of selected fish populations, Mar. Environ. Res., 112, 81-90, 2015.

Juza, M., Mourre, B., Renault, L., Gómara, S., Sebastián, K., Lora, S., Beltran, J. P., Frontera, B., Garau, B., Troupin, C., Torner, M., Heslop, E., Casas, B., Vizoso, G., and Tintoré, J.: Operational SOCIB forecasting system andmulti-platform validation in the western Mediterranean Sea, J. Oper. Oceanogr., in press, 2015.

Korres, G. and Lascaratos, A.: An eddy resolving model of the Aegean and Levantine basins for the Mediterranean Forecasting 
SystemPilot Project (MFSPP): implementation and climatological runs, Ann. Geophys. 21, 205-220, 2003.

Kourafalou, V. H., De Mey, P., Staneva, J., Ayoub, N., Barth, A., Chao, Y., Cirano, M., Fiechter, J., Herzfeld, M., Kurapov, A., Moore, A. M., Oddo, P., Pullen, J., Van Der Westhuysen, A., and Weisberg, R.: Coastal Ocean Forecasting: Science foundation and user benefits, J. Oper. Oceanogr., 8, s147-s167, 2015.

Kröger, S., Parker, E. R., Metcalfe, J. D., Greenwood, N., Forster, R. M., Sivyer, D. B., and Pearce, D. J.: Sensors for observing ecosystem status, Ocean Sci., 5, 523-535, 2009.

Launder, B. E. and Spalding, D. B.: The numerical computation of turbulent flows. Comput. Meth., Appl. Mech. Engin., 3, 269-289, 1974.

Lesser, G. R., Roelvink, J. A., van Kester, J. A. T. M., and Stelling, G. S.: Development and validation of a three dimensional morphological model, Coastal Eng., 51, 883-915, 2004.

Li, M., Zhong, L., and Boicourt, B.: Simulation of Chesapeake Bay Estuary: sensitivity to turbulence mixing parameterizations and comparison with hydrographic observations, J. Geophys. Res., 110, C12004, doi:10.1029/2004JC002585, 2005.

Lohrer, A. M., and Wetz, J. J.: Dredging-induced nutrient release from sediments to the water column in a southeastern saltmarsh tidal creek, Mar. Pollut. Bull., 46, 1156-1163, 2003.

Los, F. J., Tatman, S., and Minns, A. W.: Flyland - a future airport in the North Sea? An integrated modelling approach for marine ecology, 6th International Conference on Hydroinformatics, edited by: Liong, S. Y., Phoon, K. K., and Babovic, V., World Scientific, Publishing Co.Pte. Ltd. Singapore, ISBN 981-238-787-0, 21-24 June 2004.

Malone, T. C., DiGiacomo, P. M., Gonçalves, E., Knap, A. H., Talaue-McManus, L., de Mora, S., and Muelbert, J.: Enhancing the Global Ocean Observing System to meet evidence based needs for the ecosystem-based management of coastal ecosystem services, Nat. Res. Forum, 38, 168-181, 2014.

Manzanera, M., Pérez, M., and Romero, J.: Seagrass mortality due to oversedimentation: an experimental approach, J. Coast. Conserv., 4, 67-70, 1995.

Manzo, C., Valentini, E., Taramelli, A., Filipponi, F., and Disperati, L.: Spectral characterization of coastal sediments using Field Spectral Libraries, Airborne Hyperspectral Images and Topographic LiDAR Data (FHyL), Int. J. Appl. Earth Obs., 36, 54-68, 2015.

McBride, G., Salmond, C., Bandaranayake, D., Turner, S., Lewis, G., and Till, D.: Health effects of marine bathing in New Zealand, Int. J. Environ. Health Res., 8, 173-18, 1998.

Nayar, S., Miller, D. J., Hunt, A., Goh, B. P. L., and Chou, L. M.: Environmental effects of dredging on sediment nutrients, carbon and granulometry in a tropical estuary, Environ. Monit. Assess., 127, 1-13, 2007.

Oddo, P., Pinardi, N., and Zavatarelli, M.: A numerical study of the interannual variability of the Adriatic Sea, Sci. Total Environ., 353, 39-56, 2005.

Oddo, P., Adani, M., Pinardi, N., Fratianni, C., Tonani, M., and Pettenuzzo, D.: A nested atlantic-Mediterranean sea general circulation model for operational forecasting, Ocean Sci. 5, 461-473, 2009.

Olita, A., Dobricic, S., Ribotti, A., Fazioli, L., Cucco, A., Dufau, C., and Sorgente, R.: Impact of SLA assimilation in the Sicily
Channel Regional Model: model skills and mesoscale features, Ocean Sci., 8, 485-496, 2012.

Ondrusek, M., Stengel, E., Kinkade, C. S., Vogel, R. L., Keegstra, P., Hunter, C., and Kim, C.: The development of a new optical total suspended matter algorithm for the Chesapeake Bay, Remote Sens. Environ., 119, 243-254, 2012.

Pieralice, F., Proietti, R., La Valle, P., Giorgi, G., Mazzolena, M., Taramelli, A., and Nicoletti, L.: An innovative methodological approach in the frame of Marine Strategy Framework Directive: A statistical model based on ship detection SAR data for monitoring programmes, Mar. Environ. Res., 102, 18-35, 2014.

Pierini, S. and Simioli, A.: Wind-driven circulation model of the Tyrrhenian Sea area, J. Mar. Syst., 18, 161-178, 1998.

Pinardi, N. and Navarra, A.: Baroclinic wind adjustment processes in the Mediterranean Sea, Deep-Sea Res. Pt. II, 40, 1299-1326, 1993.

Qin, Y., Brando, V. E., Dekker, A. G., and Blondeau-Patissier, D.: Validity of SeaDAS water constituents retrieval algorithms in Australian tropical coastal waters, Geophys. Res. Lett., 34, L21603, doi:10.1029/2007GL030599, 2007.

Ruddick, K. G., De Cauwer, V., Park, Y. J., and Moore, G.: Seaborne measurements of near infrared water leaving reflectance: The similarity spectrum for turbid waters, Limnol. Oceanogr., 51, 1167-1179, 2006.

Santoleri, R., Volpe, G., Marullo, S., and Nardelli, B. B.: Open waters optical remote sensing of the Mediterranean Sea, In Remote sensing of the European seas, 103-116, Springer, Netherlands, 2008.

Sayol, J. M., Orfila, A., Simarro, G., Conti, D., Renault, L., and Molcard, A.: A Lagrangian model for tracking surface spills and SaR operations in the ocean, Environ. Model. Softw., 52, 74-82, 2014.

Schofield, O., Bergmann, T., Bissett, P., Grassle, J. F., Haidvogel, D. B., Kohut, J., Moline, M., and Glenn, S. M.: The long-term ecosystem observatory: an integrated coastal observatory, IEEE J. Oceanic Eng., 27, 146-154, 2002.

Serafino, F., Lugni, C., Ludeno, G., Arturi, D., Uttieri, M., Buonocore, Zambianchi, E., Budillon, G., and Soldovieri, F.: REMOCEAN: A flexible X-band radar system for sea-state monitoring and surface current estimation. Geoscience and Remote Sensing Letters, IEEE, 9, 822-826, 2012.

Siddorn, J., Allen, J., and Blackford, J.: Modelling the hydrodynamics and ecosystem of the North-West European continental shelf for operational oceanography, J. Mar. Sys., 65, 417-429, 2007.

Smith, R. S., Brown, O. B., Hoge, F. E., Baker, K. S., Evans, R. H., Swift, R. N., and Esaias, W. E.: Multiplatform sampling (ship, aircraft and satellite) of a Gulf stream warm core ring, Appl. Opt., 26, 2068-2081, 1987

Thoe, W.: A daily forecasting system of marine beach water quality in Hong Kong, Ph.D. Thesis, The University of Hong Kong, 1249, 2010.

Tintoré, J., Vizoso, G., Casas, B., Ruiz, S., Heslop, E., Renault, L., Iguz, T., Garau, B., Pascual, A., Martínez-Ledesma, M., GómezPujol, L., Alvarez-Ellacuría, A., Orfila, A., Alemany, F., AlvarezBerastegui, D., Reglero, P., Massuti, E., Vélez-Belchi, P., Ruiz, J., Gómez, M., Alvarez, E., and Manriquez, M.: SOCIB: The Balearic Islands Coastal Ocean observing and forecasting system responding to science, technology and society needs, Mar. Technol. Soc. J., 47, 101-117, 2013. 
Tonani, M., Pinardi, N., Dobricic, S., Pujol, I., and Fratianni, C.: A high resolution free-surface model on the Mediterranean sea, Ocean Sci., 4, 1-14, 2008.

Tonani, M., Balmaseda, M., Bertino, L., Blockley, E., Brassington, G., Davidson, F., Drillet, Y., Hogan, P., Kuragano, T., Lee, T., Mehra, A., Paranathara, F., Tanajura, C. A. S., and Wang, H.: Status and future of global and regional ocean prediction systems, J. Oper. Oceanogr., 8, s201-s220, 2015.

Tornero, V. and Ribera d'Alcalà, M.: Contamination by hazardous substances in the Gulf of Naples and nearby coastal areas: A review of sources, environmental levels and potential impacts in the MSFD perspective, Sci. Tot. Environ., 466, 820-840, 2014.

Van den Berg, G. A., Meijers, G. G., van der Heijdt, L. M., and Zwolsman, J. J.: Dredging-related mobilisation of trace metals: a case study in the Netherlands, Water Res., 35, 1979-1986, 2001.

Van Gils, J. A. G., Ouboter, M. R. L., and De Rooij, M. N.: Modelling of water and sediment quality in the Scheldt Estuary, Netherland, J. Aquat. Ecol., 27, 257-265, 1993.

Van Rijn, L. C., Walstra, D. J. R., Grasmeijer, B., Sutherland, J., Pan, S., and Sierra, J. P.: The predictability of cross-shore bed evolution of sandy beaches at the time scale of storms and seasons using process-based profile models, Coast. Eng., 47, 295327, 2003.

Vetrano, A., Napolitano, E., Iacono, R., Schroeder, K., and Gasparini, G. P.: Tyrrhenian Sea Circulation and water mass fluxes in spring 2004: observations and model results, J. Geophys. Res., 115, C06023, doi:10.1029/2009JC005680, 2010.
Vidal-Vijande, E., Pascual, A., Barnier, B., Molines, J.-M., and Tintoré, J.: Analysis of a 44-year hindcast for the Mediterranean Sea: comparison with altimetry and in situ observations, Sci. Mar., 75, 71-86, 2011.

Volpe, G., Nardelli, B. B., Cipollini, P., Santoleri, R., and Robinson, I. S.: Seasonal to interannual phytoplankton response to physical processes in the Mediterranean Sea from satellite observations, Remote Sens. Environ., 117, 223-235, 2012.

Weisberg, R. H., Barth, A., Alvera-Azcarate, A., and Zgeng, L.: A coordinated coastal ocean observing and modeling system for the West Florida continental shelf, Harmful Algae, 8, 585-597, 2009.

Windom, H. L.: Environmental aspects of dredging in the coastal zone, Crit. Rev. Env. Contr., 6, 91-109, 1976.

Zappalà, G., Caruso, G., Bonamano, S., Madonia, A., Piermattei, V., Martellucci, R., Di Cicco, A., Pannocchi, A., Stefanì, C., Borsellino, C., and Marcelli, M.: A multi-platform approach to marine environment assessment in Civitavecchia (Rome) area, J. Oper. Oceanogr., in press, 2015.

Zimmerman, L. E., Jutte, P. C., and Van Dolah, R. F.: An environmental assessment of the Charleston Ocean Dredged Material Disposal Site and surrounding areas after partial completion of the Charleston Harbor Deepening Project, Mar. Poll. Bull., 46, 1408-1419, 2003. 